\title{
Analysis of lithofacies cyclicity in the Miocene Coal Complex of the Bełchatów lignite deposit, south- central Poland
}

\author{
Wojciech Mastej ${ }^{1^{*}}$, Tomasz Bartuś ${ }^{1} \&$ Jerzy Rydlewski ${ }^{2}$ \\ ${ }^{1}$ AGH University of Science and Technology, Faculty of Geology, Geophysics and Environment \\ Protection, Department of General Geology, Environmental Protection and Geotourism, \\ al. Mickiewicza 30, 30-059 Kraków, Poland \\ ${ }^{2}$ AGH University of Science and Technology, Faculty of Applied Mathematics, Department of Differential \\ Equations, al. Mickiewicza 30, Kraków, Poland \\ *corresponding author, e-mail: wmastej@agh.edu.pl
}

\begin{abstract}
Markov chain analysis was applied to studies of cyclic sedimentation in the Coal Complex of the Bełchatów mining field (part of the Bełchatów lignite deposit). The majority of ambiguous results of statistical testing that were caused by weak, statistically undetectable advantage of either cyclicity over environmental barriers or vice versa, could be explained if only the above-mentioned advantages appeared in the neighbourhood. Therefore, in order to enhance the credibility of statistical tests, a new approach is proposed here in that matrices of observed transition numbers from different boreholes should be added to increase statistical reliability if they originated in a homogeneous area. A second new approach, which consists of revealing statistically undetectable cyclicity of lithofacies alternations, is proposed as well. All data were derived from the mining data base in which differentiation between lithology and sedimentary environments was rather weak. For this reason, the methodological proposals are much more important than details of the sedimentation model in the present paper. Nevertheless, they did reveal some interesting phenomena which may prove important in the reconstruction of peat/lignite environmental conditions. First of all, the presence of cyclicity in the sedimentation model, i.e., cyclic alternation of channel and overbank deposits, represents a fluvial environment. It was also confirmed that the lacustrine subenvironment was cut off from a supply of clastic material by various types of mire barriers. Additionally, our analysis revealed new facts: (i) these barriers also existed between lakes in which either carbonate or clay sedimentation predominated; (ii) there was no barrier between rivers and lakes in which clay sedimentation predominated; (iii) barriers were less efficient in alluvial fan areas but were perfectly tight in regions of phytogenic or carbonate sedimentation; (iv) groundwater, rather than surface flow, was the main source of $\mathrm{CaCO}_{3}$ in lakes in which carbonate sedimentation predominated; (v) a lack of cyclic alternation between abandoned channels and pools with clayey sedimentation; (vi) strong evidence for autocyclic alternation of phytogenic subenvironments and lakes in which carbonate sedimentation predominated was found in almost all areas studied.
\end{abstract}

Keywords: Markov chain method, cyclic sedimentation, vertical succession of lithofacies

\section{Introduction}

The main aim of the present paper is to propose new methodological approaches in the interpretation of Markov chain analysis as applied to describe the cyclicity of lithofacies alternations. Among sedimentologists the opinion that this analysis is not very useful is quite popular, for a number of reasons. First of all, statistical methods are not independent but complementary; hence, statistical 


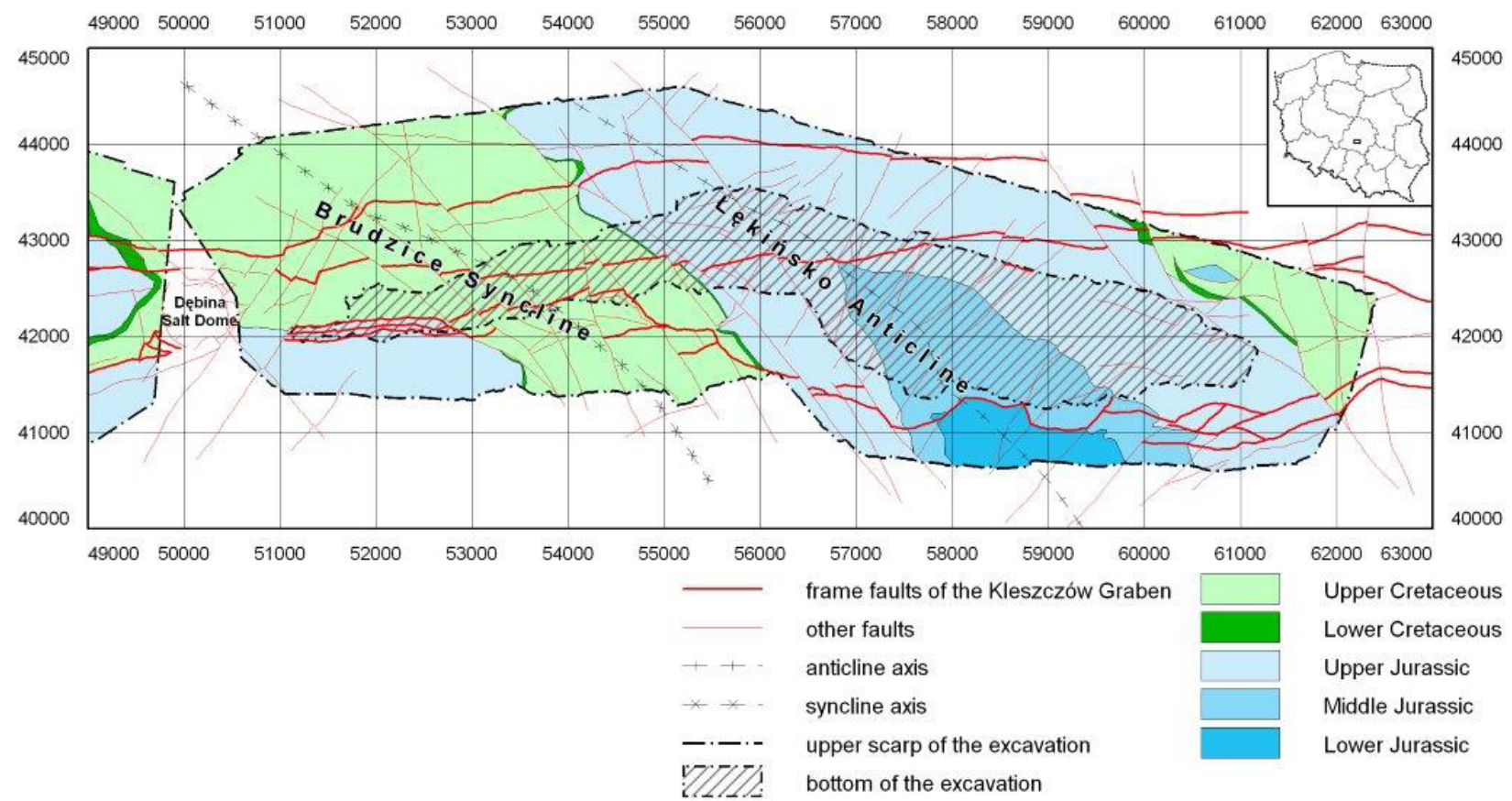

Fig. 1. Geological map of pre-Cenozoic strata in the Kleszczów Graben (Bełchatów mining field)

testing is uninterpretable without results of facies analysis. Of course, this does not imply that statistical methods are useless. Although, on the facies analysis level, the majority of elements in sedimentation model usually are revealed and statements concerning cyclicity can only be treated as hypotheses. Therefore, in our opinion, it is impossible to prove cyclic sedimentation solely on the basis of facies analysis. Conversely, statistical verification of cyclicity hypotheses is both necessary and useful. Moreover, the knowledge obtained, usually related to details of the model, is also useful because it can enrich the results of facies analysis.

Frequently expressed, unfavourable opinions about Markov chain analysis result from the fact that many of the unreliable data obtained result from improper application of this method. In our opinion, there are two sources of such errors: (i) in many papers calculations were based upon insufficient data (e.g., a single geological section and/or too many lithofacies defined), which yielded few transition numbers as expected in random cases - fewer than 5, see Yu (1984); and(ii) the popular method developed by Gingerich (1969) and Read (1969) turned out to be inappropriate for the embedded Markov chains - i.e., chains without transitions from lithofacies to themselves (Türk, 1979; Doktor et al., 2010).

Fortunately, neither of these problems plagued the present paper. In particular, the source of errors was offset by summation of information from boreholes in a homogeneous area. This methodical approach, which can enhance the credibility of sta- tistical tests, was supported by theoretical proof. It often happens that, despite an adequate number of data, noisy signal cannot be revealed by statistical tests. Under certain circumstances, however, the existence of such cyclicity can be postulated. The way to resolve this problem is illustrated by our second methodical proposal.

The second goal of this contribution is to describe the cyclicity in the Miocene Coal Complex in the Bełchatów mining field, which belongs to the Bełchatów lignite deposit. This mining field is situated within the Kleszczów Graben (Fig. 1).

Similar to other tectonic grabens in European lowlands, deposition of Neogene strata in the Kleszczów Graben commonly was cyclic (Kasiński, 1984, 2000, 2004). This cyclicity should be considered on two scales namely that of the entire graben, where the allocyclicity generally occurs; and on the local scale, where autocyclicity prevails, sometimes disturbed by allocyclicity or non-cyclic allogenic factors. However, identification of the type of cyclicity can often be erroneous (Kasiński \& Piwocki, 1994). Megacycles, i.e., first-order cycles, are the effects of allocyclicity (Kasiński, 1983, 1984, 2000). Krzyszkowski (1993) and Krzyszkowski and Winter (1996) distinguished four megacycles in the Neogene strata of the Kleszczów Graben. The oldest consists of the Subcoal Complex (mainly fluvial) and the Coal Complex with the Main Seam (various types of mires, lakes with carbonate sedimentation, alluvial fans and meandering river environments; Fig. 2). 


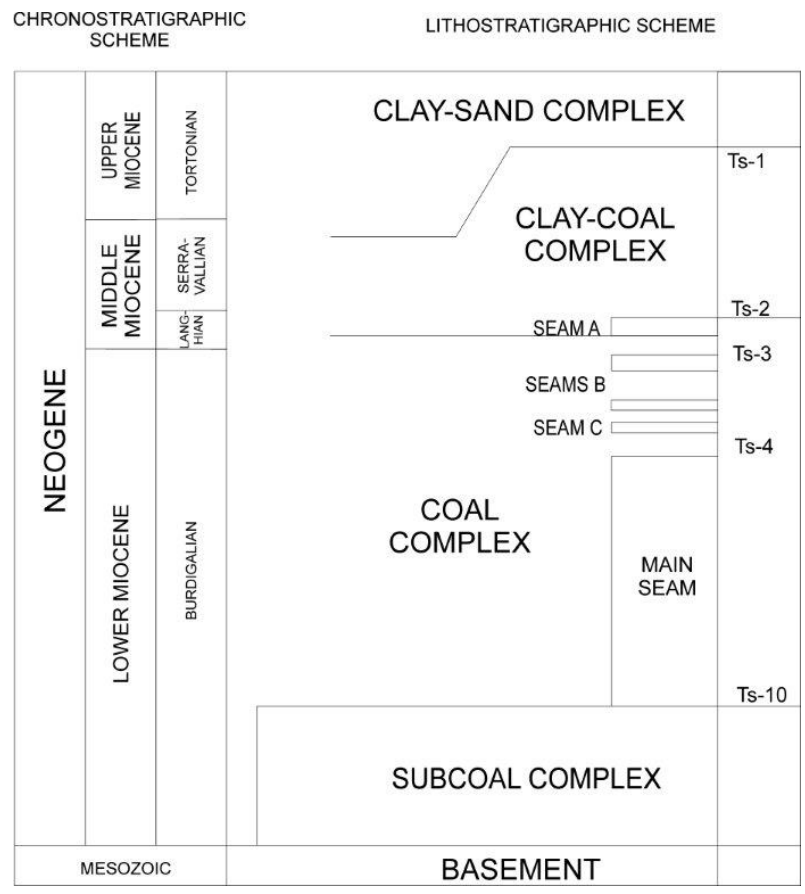

Fig. 2. Lithostratigraphy of Neogene strata in the Kleszczów Graben - Bełchatów mining field (after Czarnecki et al., 1992). Ts - paratonstein markers

Autocycles usually are of a lower order and can be identified successfully by applying statistical analysis of vertical lithofacies succession (Kasiński, 1983). Such analysis can be done using Markov chain analysis, which permits to reveal transitions between lithofacies that are significant- ly more (or less) frequent in vertical successions than they should be, i.e. when only the numbers of beds making up the transitions are considered. This method allows to formulate hypotheses concerning factors that trigger (or hamper) transitions. Transitions with statistically significant excess of frequency are the basis for studies of cyclicity in sedimentation. Interpretation of the cyclicity would be impossible without facies analysis, i.e. without linking lithofacies to relevant sedimentary environments.

In the Bełchatów mining field, facies analysis was performed for: the organic sedimentation area (Fig. 3), alluvial fans (Słomka et al., 2000; Figs. 4-5), and neighbouring lacustrine limestones (Wagner et al., 2000; Fig. 6). All deposits in these areas belong to the Coal Complex. Moreover, statistical analysis of vertical lithofacies succession was also completed for these deposits (Wagner et al., 2000; Mastej, 2002). Extrapolating these results, similar statistical studies were done for the Coal Complex in the Szczerców mining field as well as for the Subcoal Complex in the Bełchatów mining field (Mastej et al., 2003; Mastej, 2007; Wagner, 2007). A comprehensive study of bituminiferous lignite from the Bełchatów and Turów lignite deposits and carbonate strata in the Szczerców mining field was also carried out (Wagner, 1996, 2007). In depositional models proposed by Wagner et al. (2000) and Słomka et al. (2000), for the Coal Complex in the Bełchatów mining field, cyclicity was revealed but not fully confirmed sta-

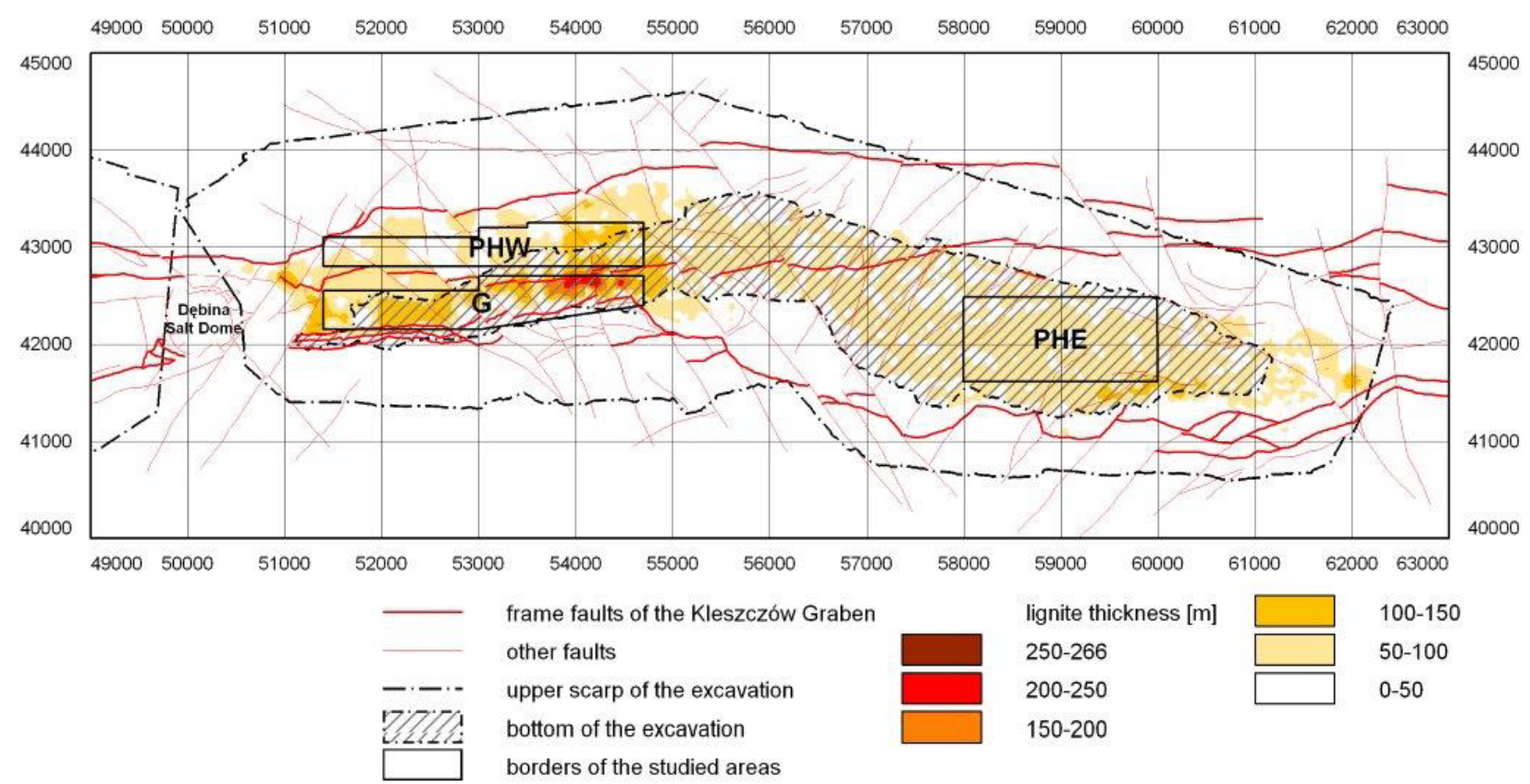

Fig. 3. Total lignite thickness in the Coal Complex of the Bełchatów mining field. G - area of phytogenic sedimentation with a high subsidence rate in the second-order graben, PHW, PHE - areas of phytogenic sedimentation with a low subsidence rate 


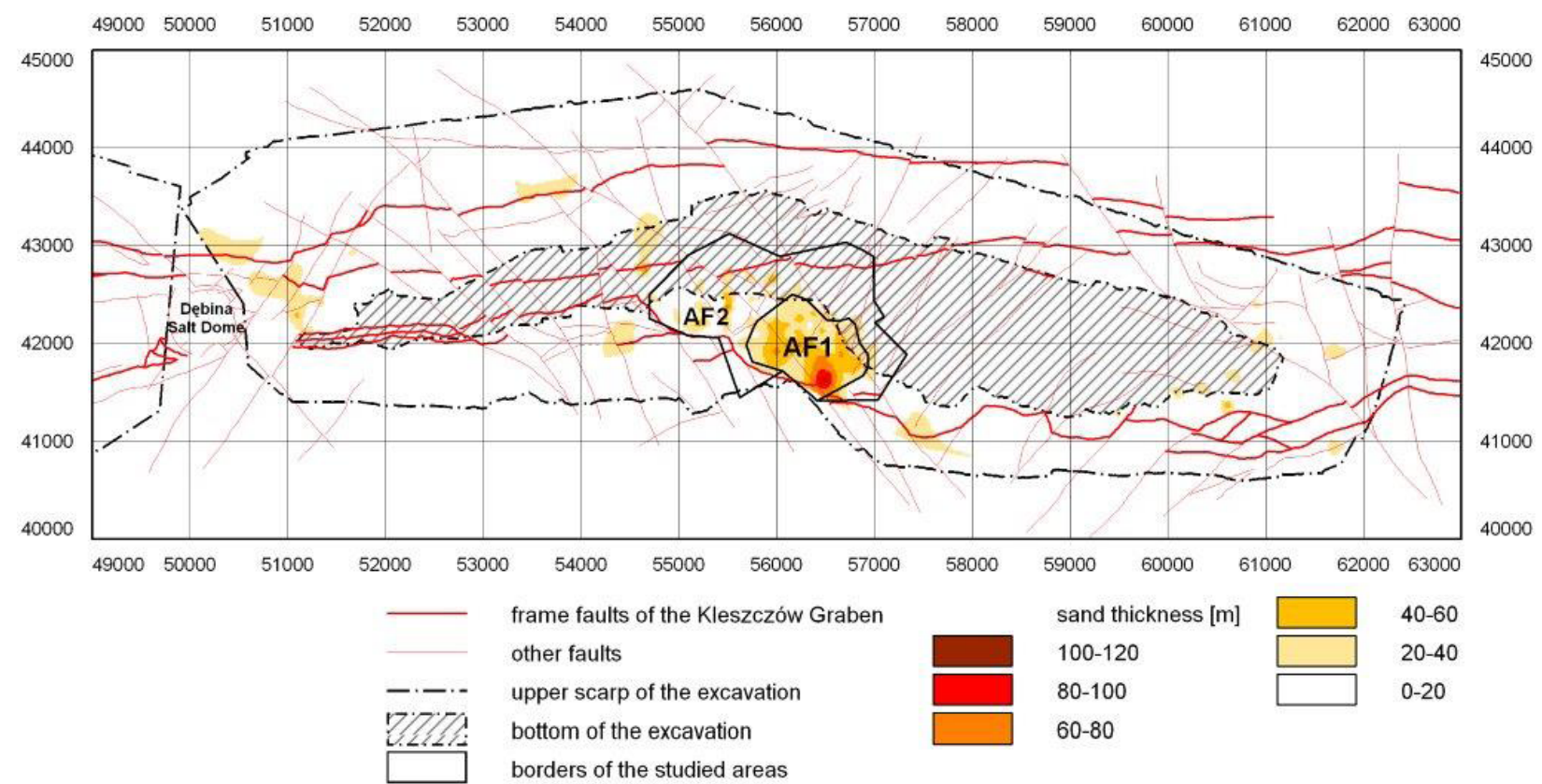

Fig. 4. Total thickness of sands in the Coal Complex of the Bełchatów mining field. AF1, AF2 - areas of phytogenic-clastic sedimentation (the AF1- proximal parts of the alluvial fans; AF2 - distal parts of the fans)

tistically. This was caused by the fact that the statistical searching methods for autocyclicity were applied only to part of the Bełchatów field (Wagner et al., 2000; Słomka et al., 2000; Mastej, 2002). The present paper aims to supplement those earlier studies, based on the drill hole data base that is property of the Bełchatów Mine. Unfortunately, the data base does not offer fully reliable connections between lithology and sedimentary environments. For this reason, the sedimentation model will play a much smaller role than the methodical one in the present contribution. Nevertheless, it did reveal some interesting phenomena, which may prove important in a reconstruction of the peat/lignite depositional environment.

\section{Geological setting and palaeogeography}

The study area is situated in the Alpine Orogeny-aged Kleszczów Graben (Fig. 1). The graben is filled with Neogene strata, which include the Bełchatów lignite deposit and the Quaternary cover. Deposits consist of two economic-grade mining areas, the Bełchatów and Szczerców lignite fields. The third area, the Kamieńsk lignite field, has recently been regarded to be non-economic. The Dębina Salt Dome with evaporates of Zechstein age separates the first two lignite occurrences (Fig. 1). The Neogene strata were subdivided into four lithostrati- graphical complexes by Czarnecki et al. (1992): Subcoal, Coal, Clay-coal and Clay-sand. Deposition of the two lower complexes proceeded under tensional regime because subsidence of the graben floor was forced by pull-apart movements in the Kleszczów Graben (Gotowała \& Hałuszczak, 1999, 2002). In earlier papers both the halokinesis and karstification of the Zechstein salts, which underlie Mesozoic strata, were assumed to have been the main factors behind the tectonic subsidence (e.g. Wysokiński \& Zapaśnik, 1984).

Sedimentation in the Kleszczów Graben was cyclic, as is commonly observed in fluvio-lacustrine environments (Kasiński, 1984). The allocyclicity often overprints the autocyclicity and vice versa. Therefore, it can be difficult to distinguish the effects of each of these components (Kasiński \& Piwocki, 1994). Tectonic subsidence was relatively marked in the early stage of Kleszczów Graben development, i.e., during deposition of the Subcoal Complex in prevailing fluvio-lacustrine environments. Thereafter, subsidence rate decreased during deposition of the Coal Complex in mainly wetland-fluvial environments and became much steadier and longer-lasting (Gotowała \& Hałuszczak, 2002; Widera \& Hałuszczak, 2011). Accommodation space, produced under such conditions, may have been compensated by peat accumulation. Therefore, phytogenic sedimentation, probably of autocyclic character, may have achieved its optimum at that time (Bohacs \& Suter, 1997; Widera \& Hałuszczak, 2011; Widera, 2013). During 


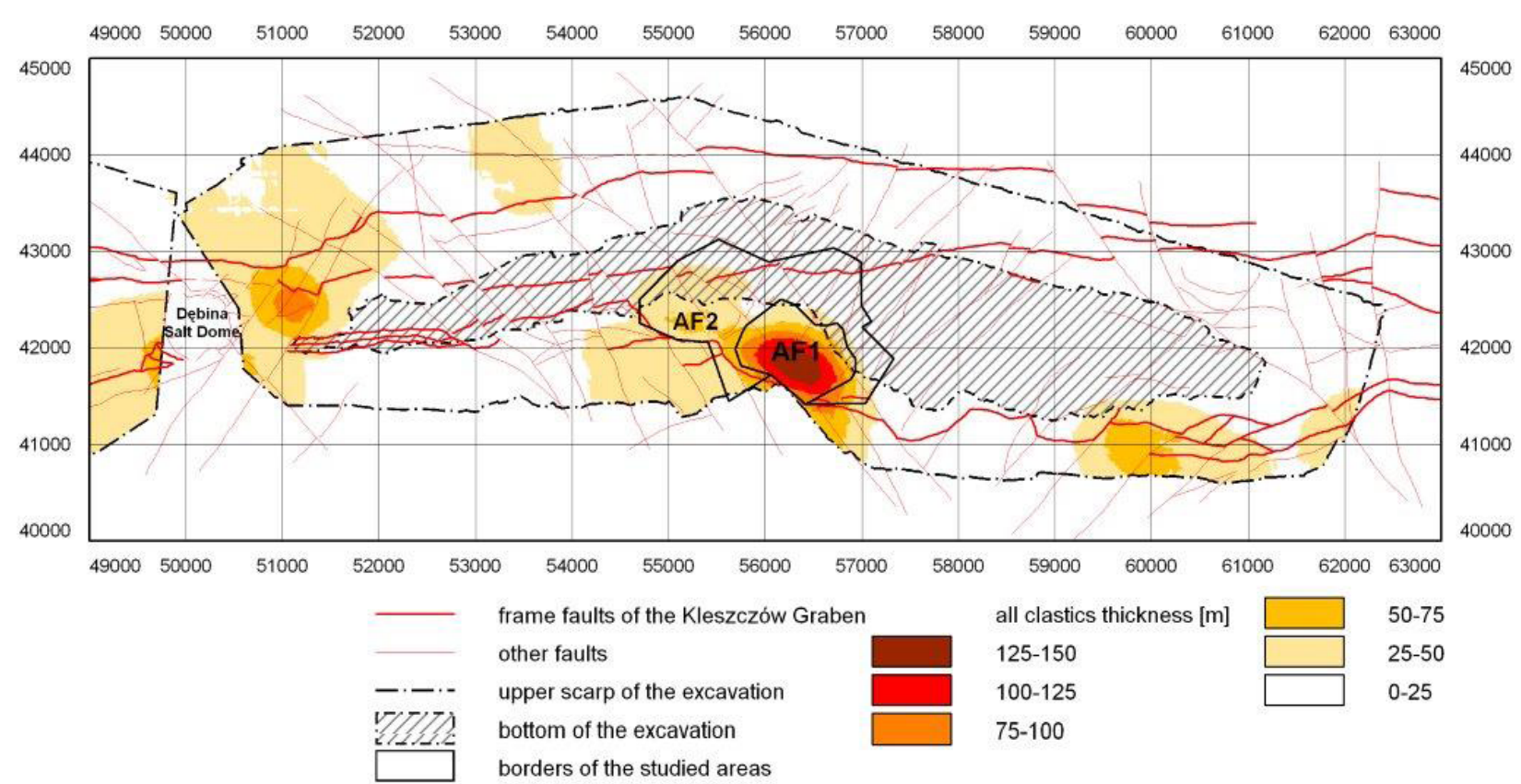

Fig. 5. Total thickness of all clastics in the Coal Complex of the Bełchatów mining field. AF1, AF2 as in Fig. 4

sedimentation of the Clay-coal Complex, cyclic alternation of subsidence rate precluded previously observed continuous phytogenic sedimentation - 2 cyclothems have been identified (Krzyszkowski \& Winter, 1996). After sedimentation of the uppermost Clay-sand Complex, most likely representing braided river deposits, the Kleszczów Graben was uplifted by compressional tectonic conditions (Gotowała \& Hałuszczak, 2002; Widera \& Hałuszczak, 2011).

The Coal Complex is the lithostratigraphic unit with the most intensive peat accumulation in the Kleszczów Graben, even though data from boreholes indicate a predominance of fluvial sediments, especially at the bottom of the complex. Under external, non-cyclic conditions, total subsidence was evened out by clastic and organic accumulation on alluvial plains (Gotowała \& Hałuszczak, 1999). However, during steadier and longer-lasting subsidence conditions phytogenic sedimentation took place. Thus, the greatest peat depocentre was located inside a second-order graben within the Kleszczów Graben, where $250.4 \mathrm{~m}$ of lignite is present in borehole no. 60/19 (Piwocki, 1992; Widera, 2013).

In the Bełchatów lignite deposit four seams have been distinguished: the lowermost, so-called 'Main Seam' (also named the D seam) and the C, B and A seams (Fig. 2). In the central part of the lignite deposit, the B, C and D seams constitute nearly the entire thickness of the Coal Complex. Recently, their boundaries have been defined by paratonstein markers (Wagner, 2000; Wagner et al., 2000). Sedimentation of the Coal Complex occurred during the late Burdigalian (Słomka et al., 2000; Fig. 2). Its base is defined by paratonstein marker Ts-10 and its top by Ts-3 (Wagner, 2000). The Main Seam is facially replaced by sandy alluvial fans at the southern-central margin of the Kleszczów Graben (Słomka et al., 2000).

In the Bełchatów mining field, three larger, isolated areas and many small ones were recognised by the authors, where ortholignites are often interbedded with lacustrine limestones (Fig. 6). From the tectonic map by Gotowała (1994), it is clear that $\mathrm{CaCO}_{3}$ was supplied into the graben from its margins, where karst processes developed (Fig. 6). The same $\mathrm{CaCO}_{3}$ provenance was proposed by Słomka et al. (2000) for the alluvial fan area and neighbouring lake deposits in which carbonates predominate. Depositional conditions of these lacustrine limestones in the Kleszczów Graben were described, amongst others, by Ciuk \& Piwocki (1967), Szwed-Lorenc \& Rascher (1982), Tomaszewski \& Cygan (1986) and Wagner et al. (2000). It should be stressed that carbonate sedimentation is more frequent in the Szczerców mining field than in the one at Bełchatów (Mastej et al., 2003; Wagner, 2007).

In the latter, a second-order graben occurs within the Kleszczów Graben (Figs. 3-6). It originated from subsidence caused by halokinesis (e.g. Hałuszczak, 1994). On account of its synsedimentary nature, the thickness of its Neogene lithostratigraphic units, and the Coal and the Subcoal complexes in particular, significantly increased. In the part studied of the Bełchatów mining field the Main Seam attains in excess of $250 \mathrm{~m}$, while in their vicin- 


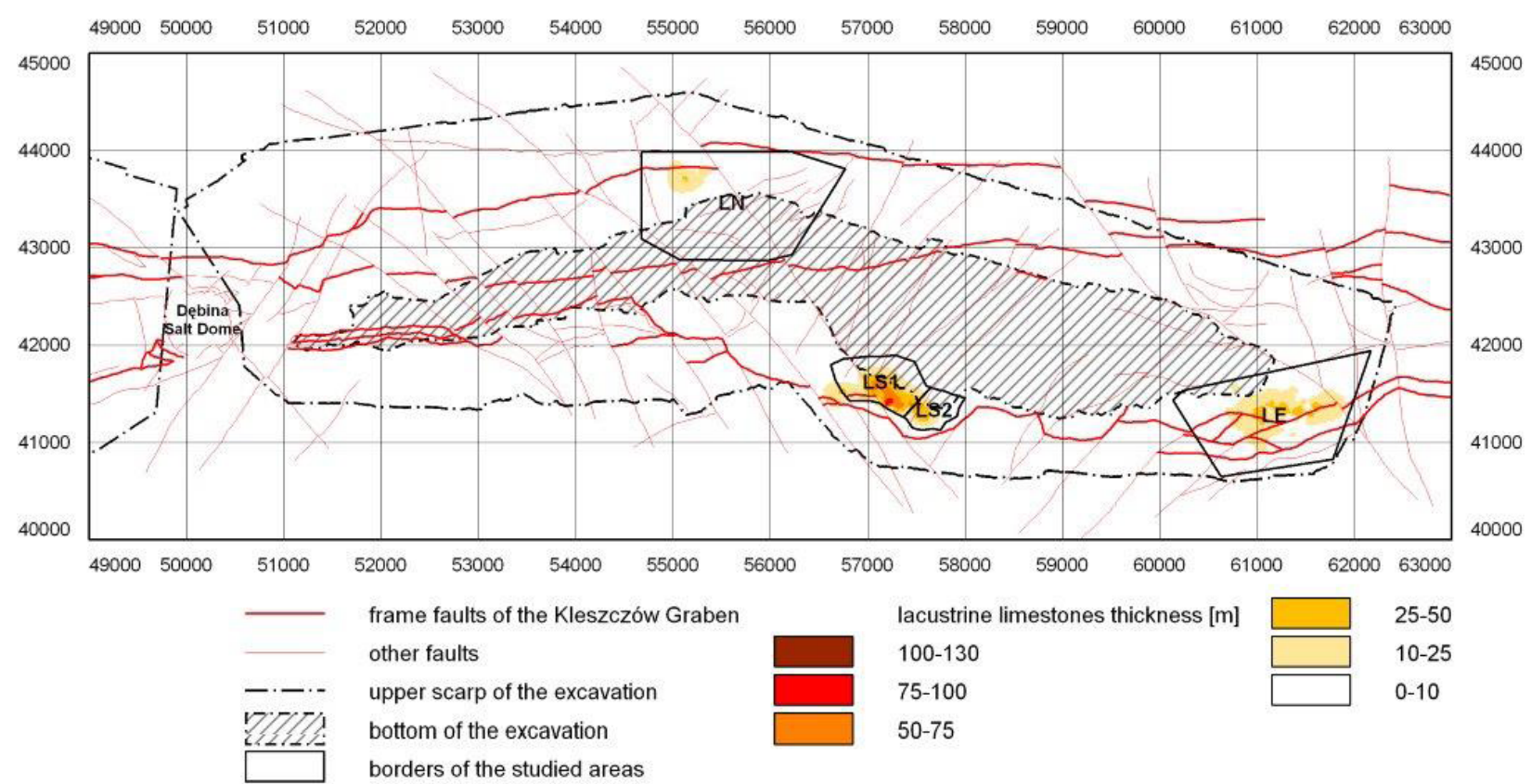

Fig. 6. Total thickness of lacustrine limestones in the Coal Complex of the Bełchatów mining field. LN, LE, LS1, LS2 areas of phytogenic-carbonate sedimentation (the LS1, LS2 areas in the south, the LE area in the east, the LN area in the north)

ity lignite seam thickness varies from between 30 and $50 \mathrm{~m}$ (Fig. 3).

\section{Materials}

Our investigations were carried out in areas representing each of the four types of sedimentation observed within the Coal Complex of the Bełchatów mining field as distinguished by Bartuś (2007). These are: two areas of phytogenic-clastic sedimentation (the AF1 area - prevailing alluvial fans, were precisely their proximal parts, and the AF2 area similar to AF1 but covering distal parts of the fans), three isolated areas of phytogenic-carbonate sedimentation (the LS area in the south, the LE area in the east, and the LN area in the north), one area of phytogenic sedimentation with a high subsidence rate in the second-order graben (the G area), and two areas of phytogenic sedimentation with a low subsidence rate- the PHE and PHW (Figs. 3-6). The alluvial fan deposits generally are located within the Coal Complex. Słomka et al. (2000) distinguished two fans, an upper and a lower, separated by lignites. The proximal parts of the fans (the AF1 area) contain more sands than the distal ones, the AF2 area (Figs. 4-5). The 25-m-isopach total thickness of sands was taken as the boundary between these two areas and the 5-m-isopach as the outer contour of the combined AF1 and AF2 areas. The distal parts of the fans demonstrated here (the AF2 area) are wider than those predicted by Słomka et al. (2000) and assumed by Mastej (2002).

The proximal parts of the fans (the AF1 area) interfinger with lacustrine limestones (the LS area, $0.7 \mathrm{~km}^{2}$ ) as reported by Wagner et al. (2000). The LS area is divided into two parts (LS1 and LS2) by steep, synsedimentary faults (Wagner et al., 2000). The LS1 area documents more frequent occupation by alluvial fans than LS2. The sand bodies of these fans led to intensified peat compaction (Słomka et al., 2000). The second and third areas of phytogenic-carbonate sedimentation were defined in the east (the LE area) and in the north (the LN area) of the Bełchatów mining field. All three, being close to the graben margin affected by extensive karst processes, were privileged sites of carbonate sedimentation. It should be noted here that lacustrine limestones are significantly less frequent in other parts of the study area.

The last three areas (G, PHE and PHW) were distinguished in places where clastic input from alluvial fans was insignificant and depositional conditions precluded carbonate sedimentation. The highest rate of peat accumulation occurred simultaneously in these areas, particularly in the G area, with the largest accommodation space. However, the subsidence rate of the mire surface should be lower than or equal to the rate of peat growth (Diessel et al., 2000; Widera, 2007, 2013).

All data were taken from the borehole data base of the Bełchatów Mine. The analysis concerned only 
Table 1. Theoretical genetic relationships between fluvio-lacustrine environments and lithofacies

\begin{tabular}{|c|c|c|c|c|c|c|c|c|}
\hline \multicolumn{9}{|c|}{ Environments } \\
\hline \multirow[b]{2}{*}{$\begin{array}{l}\text { Lithofa- } \\
\text { cies }\end{array}$} & \multicolumn{2}{|c|}{ Alluvial fan } & \multicolumn{3}{|c|}{ Meander belt } & \multicolumn{3}{|c|}{ Flood plain } \\
\hline & $\begin{array}{c}\text { Channels, } \\
\text { lobes }\end{array}$ & Levees & $\begin{array}{l}\text { Channels, cre- } \\
\text { vasse splay, } \\
\text { lake deltas } \\
\text { (Gilbert type) }\end{array}$ & Levees & $\begin{array}{c}\text { Abandoned } \\
\text { channels }\end{array}$ & $\begin{array}{l}\text { Pools } \\
\text { with } \\
\text { clayey } \\
\text { deposits }\end{array}$ & $\begin{array}{l}\text { Mires (wet and } \\
\text { dry forests and } \\
\text { mossy-grassy } \\
\text { fens), palus- } \\
\text { trine zone }\end{array}$ & $\begin{array}{c}\text { Lakes with } \\
\text { carbonate } \\
\text { deposits }\end{array}$ \\
\hline \multicolumn{9}{|c|}{ 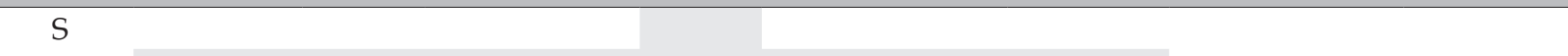 } \\
\hline \multicolumn{9}{|l|}{ M } \\
\hline \multicolumn{9}{|l|}{$\mathrm{CL}$} \\
\hline \multicolumn{9}{|l|}{$\mathrm{CC}$} \\
\hline $\mathrm{C}$ & & & & & $\begin{array}{c}\text { gyttja } \\
\text { (bituminiferous } \\
\text { lignite) }\end{array}$ & & & \\
\hline LL & & & & & & & & \\
\hline
\end{tabular}

Lithofacies are explained in the text.

those lithofacies that were sufficiently common in the cores so as to ensure reliable statistical results. This criterion was met by six lithofacies marked as: S - sand, M - mud, CL - clay, CC - coaly clay, LL -limestone and C - lignite. Sedimentary structures, contents of plant detritus in clastics, and indicators of sedimentary environments in lignites were not recorded in the data base. Thus, it was impossible to differentiate between sands and muds laid down in channel, levee or crevasse splay subenvironments. Similarly, the types of wetlands could not be identified precisely. Using the sedimentation model created by Wagner et al. (2000) and Słomka et al. (2000), and taking into account the above-mentioned limitations resulting from the quality of the well data base, an attempt was made to present a theoretically acceptable link between depositional environments/subenvironments and lithofacies. The results, included in Table 1, are as follows:

- sands (S) represent alluvial fan subenvironments: lobes and braided channels; meandering river subenvironments: channels and crevasse splays and flood plain;

- muds (M) could have been deposited in almost all subenvironments and can be regarded in particular as the main flood deposit; sands and muds are the main deposits of both alluvial fans and meandering river;

- clays (CL) are the main products of pools and abandoned channels;

- coaly clays (CC) represent shallow pools or abandoned channels with autogenic or allogenic organic matter developed on fans, meandering belts and/or on flood plains;

- limestones (LL) originated in lakes with $\mathrm{CaCO}_{3}$ supply;
- lignites (C) represent various types of mires: mossy-grassy fens, wet and dry forested swamps, bushy moors, etc. (Teichmüller, 1958, 1962; Wagner et al., 2000; Widera, 2012); the C facies could also represent bituminous lignite of the gyttja type, laid down in abandoned channels and in pools (Wagner, 1996). These two subenvironments of peat/lignite and gyttja formation are, however, poorly distinguished on the basis of data from boreholes (Table 1).

\section{Methods}

The Markov chain analysis has been successfully applied many times as support for facies analysis in order to illustrate the cyclic sedimentation (see e.g. Krawczyk, 1980; Powers \& Easterling, 1982; Calder, 1993; Słomka, 1986, 1995; Xu \& MacCarthy, 1998; Wagner et al., 2000; Słomka \& Słomka, 2001; Mastej, 2002, 2007; Mastej et al., 2003; Wagner, 2007; Doktor et al., 2010). According to Walther's law two neighbouring lithofacies in a vertical section must also be neighbours laterally (Walther, 1894). On the other hand, the transition from a lower to an upper lithofacies in a succession can be regarded as an invasion of the neighbouring environment, representing the latter which overlies the former. Therefore, if lithofacies are assigned to sedimentary environments, the cyclicity analysis of the vertical lithofacies succession enables us to investigate the cyclicity of these invasions. However, insufficient data on the link between depositional environments and lithofacies in the Bełchatów mining data base cause the results of investigation to be limited. The method is useful in the case of 
thick sedimentary successions with a large number of transitions between lithofacies, e.g. flysch or limno-fluvial strata, due to a large amount of data suited for statistical processing. A single succession from the Coal Complex, noted in a selected borehole, usually cannot supply sufficient data. Hence, the matrices of observed transition numbers (Appendix 1), computed on the basis of data from different boreholes, were added only if they originated from a homogeneous area, i.e., from one of the above-defined areas. For example, the matrix for the AF1 area was constructed by the sum of 89 matrices derived from 89 boreholes. Moreover, this final matrix generated for a selected area, representing the averaged pattern of transitions, eliminates very local and random fluctuations of transition numbers. The matrix, constructed for each of the areas, can be called the "geological profile for the area". However, this is not a synthetic section in the lithostratigraphic sense because its components, i.e., lithological sections from each borehole, are stratigraphically uncorrelated.

The Markov chain method can be applied to the sum of matrices containing data from the homogeneous geological section for the area (Powers \&Easterling, 1982; Anderson \& Goodman, 1957; Goodman, 1968). Moreover, due to the Bernoulli Law of Large Numbers, elements of the sum of matrices make for a better approximation than do elements of a single matrix. Thus, the use of the sum of matrices instead of a single matrix is much more advantageous when matrices are derived from a homogeneous area. For that reason, it is strange that papers applying such an approach have not appeared to date, with the exception of Powers \& Easterling (1982).

Additionally, the term 'profile' will be used as an abbreviation of the above-defined 'geological profile for the area'. It must be emphasised that in each of the areas studied vast data sets, which were derived from several dozens to several hundreds of boreholes with a cumulative length of several kilometres and characterised by thousands of transitions between lithofacies, were used.

In this method, the statistical testing of non-randomness of a geological profile, which is defined as a vertical lithofacies succession, is fundamental in this method. When non-randomness is found, the profile is considered as a Markov chain. Usually, the first order of the embedded Markov chains are tested, i.e., only transitions between neighbouring beds (lithofacies) are investigated, while those between beds belonging to the same class (i.e., lithofacies) are forbidden. The state-of-the-art accuracy of statistical applications allows to draw the con- clusion that the Gingerich-Read method commonly used in the past, should not be applied to either embedded or non-embedded chains (Gingerich, 1969; Read, 1969). For embedded chains the Iterative Proportional Fitting method (IPF) is recommended and the term 'quasi-randomness' should be used instead of 'randomness' (see Türk, 1979; Powers \& Easterling, 1982; Doktor et al., 2010). Details of the IPF method applied as well as a theoretical discussion of the applicability of other variants of the Markov chain analysis in sedimentology have been presented by Doktor et al. (2010).

The non-quasi-randomness of a profile does not mean that each facies transition number must be non-quasi-random. Therefore, in the case of a non-quasi-random profile, for each $i, j, i \neq j$, quasi-random numbers of transition from lithofacies $L_{i}$ to lithofacies $L_{j}\left(L_{i} \rightarrow L_{j}\right)$ can be tested separately. Here, two terms, which have already been proposed by Mastej (2007), will be used:'privileged transitions' (i.e., those with statistically significant excess of transition numbers over quasi-random transition numbers) and 'repressed transitions' (i.e., those with statistically significant deficit of transition numbers in comparison with quasi-random ones). If the excess or deficit is not significant, the transitions will be regarded as having quasi-random numbers and will be named 'quasi-random transitions'.

During the first stage of calculations, the non-quasi-randomness of whole profiles was checked by testing the significance of differences between the numbers of observed and quasi-random transitions. In the present paper, as well as in previous publications, the IPF method has been applied in order to calculate the quasi-random transition numbers (Mastej, 2002, 2007). At the second stage, in the case of non-quasi-randomness of a whole studied profile, the right-sided z-test usually is used to point out significant excess in the observed number of transitions from $i^{\text {th }}$ to $j^{\text {th }}$ facies, in relation to the quasi-random transition number. In the present paper, the double-sided z-test was applied to identify both excess and deficit in relation to the quasi-random transition numbers. The ' $z$ ' statistics was computed using the Powers and Easterling (1982) formula:

$$
z_{i j}=\left[\left(f_{i j}-e_{i j}\right) / e_{i j}\right]^{1 / 2}
$$

where:

$f_{i j}$ - observed number of transitions from $i^{\text {th }}$ to $j^{\text {th }}$ facies,

$e_{i j}$ - expected (in the case of quasi-randomness) number of transitions from $i^{\text {th }}$ to $j^{\text {th }}$ facies. 
The ' $z$ ' statistics has normal, standardised distribution in the case of the quasi-random transition number. Significance level $a=0.1$ was assumed as the maximum rejection probability of a true hypothesis that the number of transitions from $i^{\text {th }}$ to $j^{\text {th }}$ facies was quasi-random. The atypical avalue (0.1 instead of 0.05 ) resulted from the intention of revealing even the weak statistical effects of cyclicity. Privileged transitions, typically pointed out by means of a set of right-sided z-tests, are traditionally used to construct facies relationship diagrams - FRD (see Duff \& Walton, 1962; Gradziński et al., 1986). These transitions are the basis for revealing cycles in sedimentary processes.

Autocyclic sedimentation of the Coal Complex without significant disturbance of allocyclic external factors can be expected. These external factors (subsidence, clastic supply, climate change, etc.) seemed to be stable. Under such favourable conditions, autocyclic processes were caused by positive and negative feedback interplay (Beerbower, 1964). Regarding the processes at lithofacies transitions level, i.e., at the level of fluvio-lacustrine subenvironment alternation (Walther's law), it appears that both the privileged and repressed transitions reflect the specific character of autocyclicityor its absence. Therefore, in our opinion, not only should privileged transitions but also repressed ones be represented in FRD diagrams.

The repressed transitions point to out barrier action, which significantly hampered alternations of corresponding subenvironments. This action blocked off the potential development of autocyclicity, but it is also possible that there was no chance for the occurrence of autocyclicity even if no barrier existed. This is a case of strong, statistically detected effect of the advantage of barrier action over the effects of the autocyclic process. Not only do the privileged transitions suggest the lack or weakness of barriers, they also prove the existence of an autocyclic mechanism. This is a case of strong, statistically detected effect of advantage in the opposite direction, i.e. advantage of the effects of autocyclic process over barrier action.

According to common interpretation of randomness, the occurrence of quasi-random transitions neither proves the lack of autocyclicity nor eliminates the possibility of barrier action in facies transitions. These transitions may have been the result of: (i) lack of the above-mentioned advantage, i.e., either the lack of autocyclic mechanism and barriers or the occurrence of the mechanism almost completely disturbed by barrier action, (ii) weak, statistically undetectable effect of autocyclicity, i.e., weak advantage of autocyclic process over the effects of barrier action, and (iii) weak, statistically undetectable effect of barrier action, i.e., weak advantage of barrier action over the effects of the autocyclic process.

The question arises whether it is possible and useful to detect such weak, statistically undetectable effects using a method other than statistics. The findings obtained (see above) encouraged us to answer affirmatively. Hence, in reasonable cases, it is possible to put together privileged and (ii)-quasi-random transitions, as well as repressed and (iii)-quasi-random ones. Let us consider transitions $L_{i} \rightarrow L_{j}$ for two given lithofacies $L_{i} L_{i}$. When in all neighbouring areas such transitions are always privileged or have quasi-random numbers but are never repressed, it may be assumed that in cases where quasi-random numbers occurred, weak effects (ii-case) occurred as well. This enables to name the transitions $L_{i} \rightarrow L_{j}$ 'unrepressed transitions'. Similarly, it is possible todefine 'unprivileged transitions' when in all neighbouring areas transitions $L_{k} \rightarrow L_{n}$ are always repressed or have quasi-random numbers (iii-case), but are never privileged. These two terms were already proposed by Mastej (2007), but, albeit, in a different meaning. Finally, a third type of transition exists when neither of these two rules applies. They are named the 'non-stable transitions' and they have quasi-random numbers in all neighbouring areas. It should be noted that these definitions are not related to a separate area but to all neighbouring areas of the Bełchatów mining field that have been studied.

Concluding the above part of the research, unrepressed transitions are proposed elements of FRDs (facies relationship diagrams) instead of privileged ones. It is also suggested that unprivileged transitions should be introduced to the FRD in order to disclose the barriers that separate subenvironments.

\section{Results}

The sedimentation models of the Coal Complex assume a meandering river to have flowed through the Kleszczów Graben and phytogenic and lacustrine sedimentation to have proceeded on the alluvial plains (Słomka et al., 2000; Wagner et al., 2000). Moreover, alluvial fans developed along the southern margin of the graben. As suggested by Allen's (1970) model of sedimentation on a basin-scale, autocyclic sedimentation in such a fluvio-phytogenic-lacustrine environment can be expected. Theoretically, it is possible to postulate here several autocyclic processes. Non-uniform distribution of stream energy in a meander could have 
Table 2. Non-stable transitions

\begin{tabular}{lccccccccc} 
& AF1 & AF2 & LS1 & LS2 & LE & LN & G & PHW & PHE \\
\hline $1 . \mathbf{C L} \leftrightarrow \mathrm{CC}$ & $\downarrow$ & $\downarrow$ & $\downarrow$ & $\varphi$ & $\downarrow$ & $\uparrow$ & $\downarrow$ & $?$ & $\downarrow$ \\
$2 . \mathbf{C L} \leftrightarrow \mathbf{C}$ & $\uparrow$ & $\uparrow$ & $?$ & $?$ & $\downarrow$ & $\downarrow$ & $?$ & $?$ & $?$ \\
$3 . \mathrm{CC} \leftrightarrow \mathrm{LL}$ & $\varphi$ & $\uparrow$ & $\uparrow$ & $\varphi$ & $\downarrow$ & $\downarrow$ & $\varphi$ & $\varphi$ & $\varphi$ \\
$4 . \mathbf{C C} \leftrightarrow \mathbf{M}$ & $?$ & $\downarrow$ & $\uparrow$ & $\varphi$ & $\varphi$ & $\varphi$ & $\varphi$ & $\downarrow$ & $\varphi$ \\
\hline
\end{tabular}

Explanations: $\uparrow$ - privileged transitions, $\downarrow$ - repressed transitions, ? - quasi-random transition numbers of forward and reverse directions, $\varphi-$ no statistical test.

forced the meander to expand and force the layers to prograde until the meander neck was cut off (Gradziński et al., 1986; Zieliński, 2014). This would imply that the process had repeated many times and as a result a meandering belt had formed. The processes could have produced the fining-upward clastic series of the laterally migrating point bar on the convex riverbank. This fining-upward character of the sediment would be reflected in transitions between two lithofacies (two-element cycles) in the Markov chain analysis. Very local concentration of sediments in the meander belt, uncompensated by local subsidence, might have caused local lack of accommodation space which led to river avulsion (Allen, 1970; Gradziński et al., 1986; Zieliński, 2014). Fine clastic flood deposits, as well as lakes rimmed mainly by mires, are expected on alluvial plains (Wagner et al., 2000). Lakes could exist locally and temporarily in areas where there was accommodation space, especially when the groundwater level rose or increasing subsidence occurred.

The data set describing the character of cyclicity is listed in Appendix 1 and Table 2 as well as in Fig. 7. In all of the areas studied, the whole geological profiles examined were non-quasi-random. Thus, the privileged and repressed transitions, as well as the subsequent unrepressed and unprivi- leged ones, were picked out. The results revealed two regularities (Appendix 1; Table 2).

1. The first is that for two given lithofacies $L_{i^{\prime}} L_{i^{\prime}}$ if transitions $L_{i} \rightarrow L_{j}$ are unrepressed, so are reverse transitions $L_{i} \leftarrow L_{i}$. Similarly, if transitions $L_{i} \rightarrow L_{j}$ are unprivileged, so are reverse transitions $L_{i} \leftarrow L_{i}$. This rule demonstrates that both forward and reverse unrepressed transitions were caused by the same cyclic factors. Similarly, both forward and reverse unprivileged transitions were hampered by the same barriers. In the non-stable transition set, presented in Table 2, similar relationships can be observed, i.e. (i) if transitions $L_{i} \rightarrow L_{i}$ are privileged in an area, so are reverse transitions $L_{i} \leftarrow L_{j}$ in this area and (ii) if transitions $L_{i} \rightarrow L_{i}$ are repressed in an area, so are reverse transitions $L_{i} \leftarrow L_{i j}$. It should be noted that these regularities always apply; there are no exceptions.

2. The second regularity is that there are many unrepressed and unprivileged transitions in the study area. The following unrepressed transitions (Appendix 1) were found ( $\leftrightarrow$ means forward and reverse transitions): $\mathrm{S} \leftrightarrow \mathrm{M}, \mathrm{S} \leftrightarrow \mathrm{CL}$, $\mathrm{S} \leftrightarrow \mathrm{CC}, \mathrm{C} \leftrightarrow \mathrm{CC}, \mathrm{C} \leftrightarrow \mathrm{LL}$. Similarly, the following unprivileged transitions were found: $S \leftrightarrow C$, $\mathrm{S} \leftrightarrow \mathrm{LL}, \mathrm{M} \leftrightarrow \mathrm{CL}, \mathrm{M} \leftrightarrow \mathrm{C}, \mathrm{M} \leftrightarrow \mathrm{LL}, \mathrm{CL} \leftrightarrow \mathrm{LL}$. These two transition sets constituted $73 \%$ of cases in

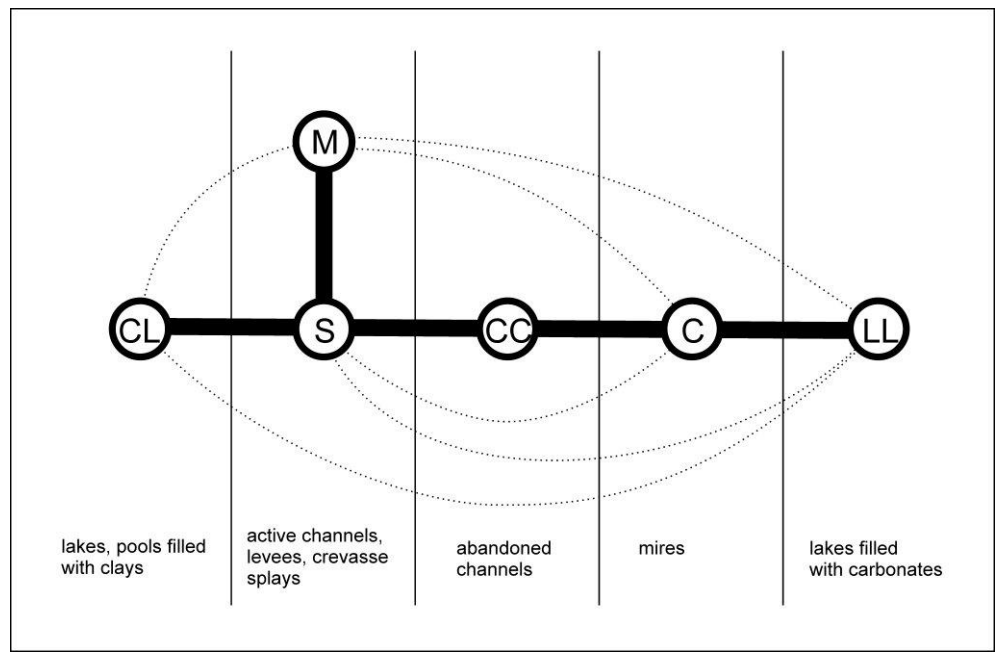

Fig. 7. Facies relationship diagram for the general character of cyclicity in the Coal Complex of the Kleszczów Graben. Sedimentary environments are linked with theoretically predominant lithofacies. Bold lines - unrepressed transitions; thin dotted lines - unprivileged transitions; arrows commonly used on FRD are omitted, because all transitions are in both directions 
the resultant matrices. The remaining $27 \%$ of cases $(\mathrm{CL} \leftrightarrow \mathrm{CC}, \mathrm{CL} \leftrightarrow \mathrm{C}, \mathrm{CC} \leftrightarrow \mathrm{LL}, \mathrm{CC} \leftrightarrow \mathrm{M})$ were related to non-stable transitions.

It should be stated here that not only did the new approach contribute in the discovery of regularities, but also the vast amount of data. Small data sets are useless in terms of revealing weak effects that still have statistical significance, e.g. cyclicity with participation of fluvial facies in an area where lacustrine-phytogenic sedimentation prevails.

The disclosed, unrepressed and unprivileged transitions were used to build the facies relationship diagram (FRD), which shows the general character of cyclicity in the Coal Complex (Fig. 7). The FRD has no arrows because all of the transitions invariably are of both forward and backward directions.

In the FRD, it is possible to distinguish two groups of sedimentary subenvironments. The first is represented by lithofacies S, M and CL. Assuming the sand lithofacies (S) to be connected with active, meandering and braided channels as well as with crevasse splay or levees, the M and CL lithofacies can be considered as belonging to the fluvial environment due to unrepressed transitions among S, M and CL lithofacies. In the Coal Complex, alluvial fans were detected by Słomka et al. (2000), and a meandering river by Wagner et al. (2000). The second group is constituted by closely connected C (wetlands/mires: raised bogs, fens, etc.) and LL (lakes with carbonate sedimentation) lithofacies.

This diversity is obligatory not only in any one selected area, but everywhere in the Coal Complex as well. Between the two groups existed almost all barriers that hampered autocyclicity, i.e. unprivileged transitions occurred. Mire barriers that rimmed the lakes with carbonate sedimentation were identified by Wagner (2000). Only one exception was recorded where barriers occurred inside the fluvial group (the $\mathrm{M} \leftrightarrow \mathrm{CL}$ unprivileged transitions). It is suggested that the pools with clay sedimentation were protected from other fluvial subenvironments with sandy lithofacies, representing active channel and/or crevasse splay infills.

The CC lithofacies played a transitional role between the two defined groups. Thus, it shows a rather weak connection with the CL lithofacies. Subsequently, the hypothesis based on Table 1, that the CC lithofacies could fill pools with clayey deposits (excluded from Fig. 7), may be rejected here. The CC lithofacies deposited in filled abandoned channels was readily replaced by phytogenic sedimentation, representing probably the fen type of mire (see Teichmüller, 1958, 1962; Widera, 2012).
The M, CL and CC lithofacies, corresponding to overbank fines, took part in probable autocyclic alternation of channel and floodplain environments, i.e., the unrepressed transitions $S \leftrightarrow M, S \leftrightarrow C L$, $\mathrm{S} \leftrightarrow \mathrm{CC}$ (Fig. 7). Such alternation is common for meandering rivers and may appear under conditions of low, stable subsidence balanced by aggradation of supplied sediment (Allen, 1970; Gradziński, et al. 1986; Zieliński, 2014). It is interesting that this autocyclic mechanism also worked in alluvial fan environments (AF2 area), where channels braided in plan view. In both types of channels, the same reason of autocyclicity can be presumed - avulsion, where local aggradation exceeded subsidence and relief became convex.

Sands representing crevasse splay deposits formed during flood episodes. Finally, these sands alternated with clastic overbank fines (M, CL, CC) during inter-flood periods.

Still, it can be argued that not only were unprivileged transitions among sands and non-clastics ( $\mathrm{S} \leftrightarrow \mathrm{C}, \mathrm{S} \leftrightarrow \mathrm{LL}$ ) hampered by the barriers, but also unprivileged transitions among fine clastics and non-clastics $(\mathrm{M} \leftrightarrow \mathrm{C}, \mathrm{M} \leftrightarrow \mathrm{LL}, \mathrm{CL} \leftrightarrow \mathrm{LL})$ were affected. This would explain the tightness of the barriers and, at the same time, provide indirect evidence that groundwater rather than surface flows could be the source of $\mathrm{CaCO}_{3}$. This means that the mire barriers hampered surface sediment flow.

In unprivileged transitions between fine clastics and non-clastics the only exception is the unrepressed $\mathrm{C} \leftrightarrow \mathrm{CC}$ transition. The most likely explanation is that the $C$ lithofacies gathered up lignites from mires, which constituted the barriers, as well as those from frequently submerged fens. The fen environment with peat sedimentation could alternate with local subenvironments of fine clastics, such as pools or abandoned channels. These environments could be fed during floods by crevasse splays. The unrepressed $S \leftrightarrow C C$ transitions show that sands could also be supplied into the subenvironments.

In the second group of subenvironments, a legible and probable autocyclic mechanism of peat and carbonate sedimentation, was observed (unrepressed C $\leftrightarrow$ LL transitions; see Fig. 7), described by Mastej (2002) in the vicinity of the distal parts of alluvial fans (the AF2 and LS1+LS2 areas). Using the method proposed, it is impossible to provide definite proof of autocyclicity against allocyclicity of the sedimentation mechanism for the alluvial fan area. However, it is easier to interpret alternations between the subenvironments mentioned as a product of the autocyclic mechanism. It is more probable that phytogenic sedimentation did not 
cover the entire fan area. Most likely, peat sedimentation extended only temporarily across the entire area (Słomka et al., 2000). In some parts of the fans peat/lignite compaction could not be evened out by clastic deposition and accommodation space needed for lake development could be created. Should the model with allocyclic sedimentation turn out to be acceptable, external factors (climate change and/ or tectonic subsidence rate) would have simultaneously produced pulses for the next sedimentary cycle in the study area.

To date, it appears to be clear that this mechanism probably extended across the Coal Complex of the Bełchatów mining field. However, it may have been particularly intensive in places located on alluvial plains, which were sites for carbonate and peat accumulation (strong evidence in AF2, LS1, LE, LN and weak in AF1, LS2; in the G, PHW, PHE areas -practically devoid of carbonates; see Appendix 1). In these areas, lacustrine limestones are repeatedly interbedded with lignites. Such facies transitions are unrepressed, which proves that a cyclic (probable autocyclic) deposition mechanism occurred. The rate of peat aggradation was balanced dynamically by the tectonic subsidence and/or compaction (Widera, 2007, 2013). A temporary advance in subsidence rate (autocyclic mechanism) forced flooding of the fens and other type of mires, and created lakes in which carbonate sedimentation took place. In the next stage, when both rates (peat aggradation and compaction-, tectonic-induced subsidence) were balanced, the lakes progressively became shallower. A legible regression series inside the carbonate deposits was found by Wagner et al. (2000) in the LS area. The shallow lake was then overgrown from the shorelines or by floating peat mats, which caused water acidification and resulted in a halt of carbonate sedimentation. Acidification was probably increased by the shallowing, i.e., a lesser amount of water could become more acid. Nevertheless, Wagner et al. (2000) did not find any strong evidence of autocyclic alternation between the shallowest carbonate facies and lignites in the LS area - the number of statistically insignificant transitions is greater than the quasi-random number. However, such evidence was indeed found in the neighbouring Szczerców mining field (Wagner, 2007). Up to the next episode of increasing subsidence the lake evolved and expanded wholly or in part into surrounding areas that were covered by mires, including fens.

Both the northern and western shores of the permanently renewing lake in the LS area were surrounded by mires and subenvironments grading between fens and other types of mire (Wagner et al., 2000). The sedimentary basin was close to the meandering river and the land was mainly forested or covered by mossy, grassy fens, etc. (Wagner et al., 2000). The mire at the western lakeside would have been a barrier against invasion of the neighbouring alluvial fans (Wagner et al., 2000).

Exceptions from the general character of cyclicity in the various subenvironments of the Coal Complex are non-stable transitions. It is surprising to see that only four such exceptions existed in the study area. CL $\leftrightarrow$ CC transitions were generally repressed (Table 2), as already interpreted by Mastej (2002) to be a lack of autocyclic alternation between pools with clay sedimentation and abandoned channels. Moreover, it seems that these subenvironments were not only separated by barriers, but were also distant from each other. The CL lithofacies may have been laid down mainly in lakes or ephemeral pools, probably inside meandering belts or even inside alluvial fans (Wagner et al., 2000; Słomka et al., 2000). In the pools (lakes), eutrophication was probably hampered (repressed transitions CL↔CC) by the decay of organic matter. Cyclicity was especially observed in the LN area, where the continuous growth of plants (CC lithofacies) was probably interrupted by invasions of small streams, rather than by floods (CL lithofacies).

The repressed $\mathrm{CL} \leftrightarrow \mathrm{C}$ and $\mathrm{CC} \leftrightarrow \mathrm{LL}$ transitions found in the LE and LN areas can be interpreted as an effect of properly working, tight barriers (Table 2). The CL $\leftrightarrow \mathrm{C}$ transitions are not surprising because the CL and C lithofacies belong to two different groups. Abandoned channels (CC lithofacies) could be converted into mires (C lithofacies), but not into lakes with carbonate sedimentation (LL lithofacies). However, the barriers did not halt the supply of fine clastics to sites of phytogenic and carbonate sedimentation on alluvial fans (AF1+AF2), nor to the neighbouring permanent carbonate sedimentation zone (LS1).

Interesting results were obtained in the areas of phytogenic sedimentation (G, PHW, PHE), particularly in the zone characterised by high subsidence rate $(G)$. Fluvio-lacustrine deposits are practically absent in these areas and the sand and limestone facies are rare (Fig. 6). This is a significant difference with respect to other areas. We expect these phenomena to have been linked to a small number of lithofacies changes in the quasi-random transitions, which, in many cases, precluded statistical testing (Appendix 1). However, if only tests done are taken into account and the absence of the LL lithofacies is removed from the equation, there are no differences in the general facies relationship diagram between the three phytogenic sedimentation zones and other areas (Fig. 7). 


\section{Summary}

Markov chain analysis was applied to studies of cyclic sedimentation within the Miocene Coal Complex of the Bełchatów mining field, forming part of the Bełchatów lignite deposit.These were carried out in four areas of different sedimentary character: phytogenic, phytogenic-carbonate, phytogenic with high subsidence rate, and phytogenic-alluvial. In the first three, overbank fines prevail, while the fourth represents channels, levees and crevasse splay facies. Fluvial facies originated most likely from a meandering river in the form of levees and crevasses, and from alluvial fans formed along the southern margin of the Kleszczów Graben.

The results obtained supplement and substantiate sedimentation models published by Słomka et al. (2000) and Wagner et al. (2000). The autocyclic alternation of channel deposits and overbank fines, known in fluvial subenvironments, was demonstrated. Moreover, strong evidence was found for the fact that the lakes with carbonate sedimentation were blocked from supply of clastic material by mire barriers. Presumably, these barriers (of various types) rimmed the lakes. It is suggested that these mires and lakes were separated from the fluvial system. However, within the fluvial system wetlands with lakes filled by clayey sediments existed.

The Markov chain analysis revealed new information: (i) the above-mentioned barriers existed between two types of lakes, i.e., with carbonate sedimentation and with clay sedimentation; (ii) there was no barrier between rivers and lakes with clay sedimentation; (iii) the barriers were less effective in alluvial fan areas but they were perfectly tight in the areas of phytogenic or carbonate sedimentation; (iv) ground water, rather than surface flow, was the main source of $\mathrm{CaCO}_{3}$ in the lakes with carbonate sedimentation; (v) an absence of autocyclic alternation between abandoned channels and pools with clay sedimentation was observed; (vi) strong proof was found for probable autocyclic alternation of phytogenic sedimentation subenvironments and lakes with carbonate sedimentation in all areas studied.

Moreover, the present study provided some methodological results. The cyclic alternation of limno-fluvial subenvironments within the Coal Complex of the Kleszczów Graben is expressed by cyclic transitions of relevant lithofacies in a geological succession. The privileged transitions (statistically significant excess of transition numbers over quasi-random transition numbers) as well as the transitions with quasi-random numbers, but not repressed ones (statistically significant deficits of transitions numbers in relation to quasi-random transition numbers),were defined as unrepressed transitions if these configurations repeated in all neighbouring areas. Similarly, the unprivileged transitions were defined as repressed transitions or transitions having quasi-random numbers, but not privileged ones. The terms privileged, repressed, unrepressed and unprivileged transitions are here proposed. In these transitions, two regularities were revealed: (i) - each transition from lithofacies A to lithofacies B and vice versa had the same character - both transitions were unrepressed or unprivileged or non-stable (i.e., neither unrepressed nor unprivileged); (ii) - 73 per cent of transitions had the same character in all areas studied, i.e., they were either unrepressed or unprivileged. Simultaneously, the privileged transitions, which have traditionally been used in facies relationship diagrams, and the repressed transitions did not reveal either regularity. It is proposed that both regularities provide a new methodological approach to the construction of facies relationship diagrams for fluvio-lacustrine environments. The diagrams, which are applied in the search for cyclicity of sedimentation, should reveal unrepressed transitions, but not privileged ones. Additionally, it is proposed that unprivileged transitions may also be marked in the diagrams. This allows the construction of generalised diagrams if the transitions have the same character in all areas, which consequently leads to the record of generalised autocyclicity. All deviations from this model (27 per cent of non-stable transitions) reflect differences in sedimentation character between the areas studied.

\section{Acknowledgements}

The project was financially supported through AGH University grant no. 11.11.140.173. Sincere thanks are due to the staff of the geological department of the Bełchatów Lignite Mine.

\section{References}

Allen, J.R.L., 1970. Studies in fluviatile sedimentation: a comparison of fining upwards cyclothems, with special reference to coarse member composition and interpretation. Journal of Sedimentary Petrology 40, 298-323.

Anderson, T.W. \& Goodman, L.A., 1957. Statistical Inference about Markov Chains. The Annals of Mathematical Statistics 28, 89-110.

Bartuś, T., 2007. Przyczynek do badań lokalnej poziomej zmienności głównych parametrów jakości węgla brunatnego w centralnej części złoża Bełchatów. Analizy statystyczne [Contribution to research of the local, 
horizontal variability the main lignite qualitative parameters in the central part of the Bełchatów lignite deposit. Statistical analyses]. Kwartalnik Geologia, 33, 89-107.

Beerbower, J.R., 1964. Cyclothems and cyclic depositional mechanisms in alluvial plain sedimentation. [In:] D.F. Merriam (Ed.): Symposium of cyclic sedimentation, Kansas Geological Survey Bulletin, 169, 31-42.

Bohacs, K.M. \& Suter, J.R., 1997. Sequence stratigraphic distribution of coaly rocks: fundamental controls and paralic examples. AAPG Bulletin 81, 1612-1639.

Calder J., H., 1993. The evolution of the ground-water influenced (Westphalian B) peat-forming ecosystem in a piedmont setting: The No. 3 seam, Springhill coalfield, Cumberland Basin, Nova Scotia. [In:] J.C. Cobb (Ed.): Modern and Ancient Coal-Forming Environment: Boulder, Colorado, Geological Society of America Special Paper 286 pp.

Ciuk, E. \& Piwocki, M., 1967. Mioceńskie wapniste osady jeziorne w złożu węgla brunatnego "Bełchatów" [Miocene lacustrine limestones in the Bełchatów lignite deposit]. Przegląd Geologiczny 15, 399-406.

Czarnecki, L., Frankowski, J. \& Kuszneruk, J., 1992. Syntetyczny profil litostratygraficzny utworów trzeciorzędu w złożu "Bełchatów” [Synthetic lithostratigraphic profile of the Tertiary sediments in the "Bełchatów" deposit]. Geologia Formacji Węglonośnych Polski, AGH, Kraków, 18-23.

Diessel, C., Boyd, R., Wadsworth, J., Leckie, D. \& Chalmers, G., 2000. On balanced and unbalanced accommodation/peat accumulations ratios in the Cretaceous coals from Gates Formation, Western Canada, and their sequence-stratigraphic significance. International Journal of Coal Geology 43, 143-186.

Doktor, M., Krawczyk, A. \& Mastej, W., 2010. Testing the randomness of lithostratigraphic successions with the Markov Chain methods. Annales Societatis Geologorum Poloniae 80, 163-166.

Duff, P.McL.D. \& Walton, E.K., 1962. Statistical basis for cyclothems: a quantitative study of the sedimentary succession in the East Pennine Coalfield. Sedimentology 1, 235-255.

Gingerich, P.D., 1969. Markov analysis of cyclic alluvial sediments. Journal of Sedimentary Petrology 39, 330-332.

Goodman, L.A., 1968. The analysis of cross-classified data. Journal of the American Statistical Association 63, 1091-1131.

Gotowała, R., 1994. Model tektoniki rowu Kleszczowa interpretacja danych z wykorzystaniem metod komputerowych [The Kleszczów Graben tectonic model interpretation with computer methods aid]. Tektonika rowu Kleszczowa - stan badań i główne zadania w aspekcie eksploatacji górniczej. Bełchatów, 91-103.

Gotowała, R. \& Hałuszczak, A., 1999. Pozycja i główne etapy młodoalpejskiego rozwoju rowu Kleszczowa w świetle badań mezostrukturalnych w odkrywce KWB „Bełchatów” i numerycznej analizy wyników wierceń [Position and main stages of development of the young-Alpine Kleszczów Graben in the light of mesostructure analysis in the outcrop of the KWB „Bełchatów" and numerical analysis of the results of drillings]. Młodoalpejski rów Kleszczowa: rozwój i uwarunkowania w tektonice regionu, Słok k. Bełchatowa, 23-36.

Gotowała, R. \& Hałuszczak, A., 2002. The late Alpinie structural development of the Kleszczów graben (central Poland) as a result of reactivation of pre-existing, regional dislocations. EGU Stephan Mueller Special Publication Series 1, 137-150.

Gradziński, R., Kostecka, A., Radomski, A. \& Unrug, R., 1986. Zarys sedymentologii [Outline of sedimentology]. Wydawnictwa Geologiczne, Warszawa, 628 pp.

Hałuszczak, A., 1994. Główne etapy ewolucji strukturalnej utworów kenozoicznych rowu Kleszczowa [The main stages of structural evolution of the Cenozoic Kleszczów Graben]. Tektonika rowu Kleszczowa - stan badań i główne zadania w aspekcie eksploatacji górniczej. Bełchatów, 78-90.

Kasiński, J.R., 1983. Mechanizmy sedymentacji cyklicznej osadów trzeciorzędowych w zapadliskach przedpola Sudetów [Mechanisms of cyclic sedimentation of the Tertiary sediments in the depressions of the Sudety foreland]. Przeglad Geologiczny 4, 237-243.

Kasiński, J.R., 1984. Tektonika sedymentacyjna jako czynnik warunkujący sedymentację formacji brunatnowęglowej w zapadliskach tektonicznych na obszarze zachodniej Polski [Sedimentary tectonics as a factor influencing of sedimentation of the lignite formation in the Western Poland Tertiary tectonic depressions]. Przeglad Geologiczny 5, 260-268.

Kasiński, J.R., 2000. Geological atlas of the Tertiary lignite-bearing association in the Polish part of the Zittau Basin. Państwowy Instytut Geologiczny, Warszawa.

Kasiński, J.R., 2004. Paleogen i neogen w zapadliskach i rowach tektonicznych [Paleogene and Neogene in depressions and tectonic grabens]. [In:] T.M. Peryt \& M. Piwocki, (Eds): Budowa geologiczna Polski. Stratygrafia. Trzeciorzęd, 3a. Państwowy Instytut Geologiczny, Warszawa, 134-161.

Kasiński, J.R. \& Piwocki M., 1994. Tektonika złoża węgla brunatnego rejonu Bełchatowa [Tectonics of the lignite deposit in the Bełchatów area]. Tektonika rowu Kleszczowa - stan badań i główne zadania w aspekcie eksploatacji górniczej. Bełchatów, 9-17.

Krawczyk, A.J., 1980. Niektóre cechy sedymentacji fliszu podhalańskiego [Some characteristics of the sedimentation process of the Podhale Flysh]. Rocznik Polskiego Towarzystwa Geologicznego, 50, 55-98.

Krzyszkowski, D., 1993. Neogene fluvial sedimentation in the Kleszczów graben, Central Poland. Journal of Sedimentary Petrology 63, 204-217.

Krzyszkowski, D. \& Winter, H., 1996. Stratigraphic position and sedimentary features of the tertiary uppermost fluvial member in the Kleszczów graben, Central Poland. Annales Societatis Geologorum Poloniae 66, 17-33.

Mastej, W., 2002. An application of Markov chain analysis to studies on lithofacies sequences in the alluvial fans from the "Bełchatów" lignite deposit (Poland). Annales Societatis Geologorum Poloniae 72, 271-282.

Mastej, W., 2007. Statistical analysis of vertical lithofacies successions in building of sedimentation model of the 
sublignite complex in the Bełchatów mining field (the „Bełchatów" lignite deposit, central Poland). Sedimentologica 1, 40-48.

Mastej, W., Słomka, T, Wagner, M., Leśniak, T. \& Słomka, E., 2003. An application of Markov chain analysis to preliminary studies on lithofacies sequences in the "Bełchatów" lignite deposit, "Szczerców" Field (Poland). Proceedings of the IAMG 2003 conference, Portsmouth, UK, 45.

Piwocki, M., 1992. Zasięg i korelacja głównych grup trzeciorzędowych pokładów węgla brunatnego na platformowym obszarze Polski [Extent and correlations of main groups of the Tertiary lignite seams on Polish platform area]. Przeglad Geologiczny 40, 281-286.

Powers, D.W. \& Easterling, R.G., 1982. Improved methodology for using embedded Markov chains to describe cyclical sediments. Journal of Sedimentary Petrology, 52, 913-923.

Read, W.A., 1969. Analysis and simulation of Namurian sediments in Central Scotland using a Markov-process model. Mathematical Geology 1, 199-219.

Słomka, T., 1986. Statistical approach to study of flysch sedimentation - Kimmeridgian-Hauterivian Cieszyn beds, Polish Outer Carpathians. Annales Societatis Geologorum Poloniae 56, 227-336.

Słomka, T., 1995. Deep-marine siliciclastic sedimentation of the Godula Beds, Carpathians. Prace Geologiczne PAN 139, 1-131.

Słomka, T., Doktor, M., Wagner, M. \& Matl, K., 2000. Sedimentological study of Miocene alluvial fans in the Bełchatów lignite deposit. [In:] T. Słomka \& M. Wagner (Eds): Charakter petrograficzny i warunki sedymentacji wybranych kompleksów litologicznych $\mathrm{z}$ profilu miocenu w złożu węgla brunatnego Bełchatów [Petrological studies and sedimentological conditions of select lithologic series in Miocene from Bełchatów lignite deposit, Poland]. Prace Geologiczne PAN 147, 21-46.

Słomka, T. \& Słomka, E., 2001. Sequences of the lithofacies and depositional intervals in the Godula beds of the Polish Carpathians. Annales Societatis Geologorum Poloniae 71, 35-42.

Szwed-Lorenc, J. \& Rascher, J., 1982. O petrografii i genezie gytii ze złoża węgla brunatnego „Bełchatów” [On petrography and genesis of gytia in the Bełchatów brown coal deposits]. Kwartalnik Geologiczny 26, 525532.

Teichmüller, M., 1958. Rekonstruktion verschiedener Moortypen des Hauptflözes der niederrheinischen Braunkohle. Fortschritte in der Geologie von Rheinland und Westfalen 2, 599-612.

Teichmüller, M., 1962. Die Genese der Kohle. Compte Ren$d u$ du quatrième Congrès pour l'avancement des etudes de Géologie du Carbonifere, Heerlen 3, 669-722.

Tomaszewski, J. \& Cygan, J., 1986. Uwagi o litologii i genezie wapieni jeziornych ze złoża węgla brunatnego „Bełchatów" [Remarks on lithology and origin of Tertiary lacustrine limestones in the Bełchatów browncoal deposit]. Kwartalnik Geologiczny 30, 77-90.
Türk, G., 1979. Transition analysis of structural sequences: Discussion. Geological Society of America Bulletin 90, 989-991.

Wagner, M., 1996. Węgiel brunatny bitumiczny ze złóż Turów i Bełchatów w świetle badań petrograficzno-chemicznych i sedymentologicznych [The bituminiferous lignite from the Turów and Bełchatów brown coal deposits and its petrographic-chemical and sedimentological studies]. Prace Geologiczne PAN, 143, 7-107.

Wagner, M., 2000. Petrografia i praktyczne znaczenie paratonsteinów ze złoża węgla brunatnego Bełchatów [Petrography and practical significance of tonsteins from the Bełchatów lignite deposit]. [In:] T. Słomka \& M. Wagner (Eds): Charakter petrograficzny i warunki sedymentacji wybranych kompleksów litologicznych $\mathrm{z}$ profilu miocenu $\mathrm{w}$ złożu węgla brunatnego Bełchatów [Petrological studies and sedimentological conditions of select lithologic series in Miocene from Bełchatów lignite deposit, Poland]. Prace Geologiczne PAN 147, 101-122.

Wagner, M., 2007. Zmienność petrologiczno-sedymentologiczna i własności technologiczne kredy jeziornej w osadach neogenu typu wapiennego zapadliska tektonicznego na przykładzie złoża węgla brunatnego "Szczerców” [Petrological and sedimentological variability and technological property of the lacustrine chalk in neogen deposits of type calcareous deep tectonic trough in "Szczerców" lignite deposit]. Wydawnictwa AGH, Kraków, 98 pp.

Wagner, M., Słomka, T. \& Doktor, M., 2000. Skład petrograficzny i warunki sedymentacji wapieni jeziornych ze złoża węgla brunatnego Bełchatów [Petrographic composition and conditions of sedimentation of lacustrine limestones from the Bełchatów lignite deposit]. [In:] T. Słomka \& M. Wagner (Eds): Charakter petrograficzny i warunki sedymentacji wybranych kompleksów litologicznych z profilu miocenu w złożu węgla brunatnego Bełchatów [Petrological studies and sedimentological conditions of select lithologic series in Miocene from Bełchatów lignite deposit, Poland]. Prace Geologiczne PAN, 147, 47-73.

Walther, J., 1894. Einleitung in die Geologie als historische Wissenschaft. Bd. 3, Lithogenesis den Gegenwart. Fischer-Verlag, Jena, 535-1055.

Widera, M., 2007. Litostratygrafia i paleotektonika kenozoiku podplejstoceńskiego Wielkopolski [Lithostratigraphy and palaeotectonics of the sub-Pleistocene Cenozoic of Wielkopolska]. Adam Mickiewicz University Press, Poznań, 224 pp.

Widera, M., 2012. Macroscopic lithotype characterisation of the 1st Middle-Polish (1st Lusatian) Lignite Seam in the Miocene of central Poland. Geologos 18, 1-11.

Widera, M., 2013. Changes of the lignite seam architecture - a case study from Polish lignite deposits. International Journal of Coal Geology 114, 60-73.

Widera, M. \& Hałuszczak, A., 2011. Stages of the Cenozoic tectonics in central Poland: examples from selected grabens. Zeitschrift der Deutschen Gesellschaft für Geowissenschaften 162, 203-214.

Wysokiński, L. \& Zapaśnik, T., 1984. Poligeniczność tektonicznego rowu Kleszczowa [Polygenic devel- 
opment of the tectonic Kleszczów Graben]. Technika Poszukiwań Geologicznych 2, 2-6.

Xu, H. \& MacCarthy, I.A.J., 1998. Markov chain analysis of vertical facies sequences using a computer software package (SAVS): Courtmacsherry formation (Tournaisian), southern Ireland. Computer and Geosciences 24, 131-139.

Yu, J., 1984. Tests for quasi-independence of embedded Markov chains. Mathematical Geology 16, 267-282.
Zieliński, T., 2014. Sedymentologia. Osady rzek i jezior [Sedimentology. Deposits of rivers and lakes]. Adam Mickiewicz University Press, Poznań, 594 pp.

Manuscript received: 28 May 2015 Revision accepted: 10 September 2015

\section{Appendix 1. Matrices of observed numbers of transitions with the results of the double-sided statistical tests.}

Legend:

S, M, CL, CC, C, LL - the lithofacies (explained in the text)

AF1, AF2, LS1, LS2, LE, LN, G, PHW, PHE - the studied areas (explained in the text)

Tests for transitions from lithofacies $L i$ to $L j$ can be found in cell at intersection of $i$ th row and $j$ th column of the matrix

XXX (black or white) - lack of the test (the quasi-random transition number is less than 5)

The first number - the number of transitions observed

The second one (after slash) - expected transition number in case of quasi-random transitions

The third one (in brackets) - probability of rejection of a true statistical hypothesis that number of observed transition is quasi-random

" + " - excess over random transition number

"-" - deficit below random transition number

Bold characters (black or white) - privileged (or repressed) transitions: statistically significant (alpha=0.1) excess (or deficit respectively) of transition numbers over quasi-random transition numbers

Non-bold characters (black or white) - statistically insignificant (alpha=0.1) difference of transition numbers in relation to over quasi-random transition numbers

White background - unrepressed transitions

Black background - unprivileged transitions

Gray background - non-stable transitions

\begin{tabular}{|c|c|c|c|c|c|c|}
\hline AF1 & $S$ & $\mathrm{M}$ & $\mathrm{CL}$ & $\mathrm{CC}$ & $\mathrm{C}$ & LL \\
\hline S & $\ddot{*}$ & $95 / 81(+0.13)$ & $211 / 204(+0.63)$ & $79 / 64(+0.07)$ & $234 / 269(-0.03)$ & $X X X$ \\
\hline $\mathbf{M}$ & $101 / 81(+0.03)$ &.. & $36 / 59(-0.00)$ & $24 / 19(+0.21)$ & $77 / 78(-0.92)$ & $X X X$ \\
\hline CL & $217 / 202(+0.30)$ & $47 / 59(-0.13)$ & $\cdot \cdot$ & $16 / 46(-0.00)$ & $221 / 194(+0.05)$ & $X X X$ \\
\hline $\mathrm{CC}$ & $86 / 64(+0.00)$ & $23 / 18(+0.28)$ & $17 / 46(-0.00)$ &.. & $63 / 61(+0.79)$ & $X X X$ \\
\hline $\mathrm{C}$ & $212 / 265(-0.00)$ & $71 / 77(-0.52)$ & $240 / 193(+0.00)$ & $71 / 61(+0.19)$ & & $X X X$ \\
\hline LL & XXX & XXX & $X X X$ & XXX & XXX & .. \\
\hline
\end{tabular}

Data: 89 boreholes, total profile length: $7.22 \mathrm{~km}, \mathrm{~m}=5$ lithofacies (without the LL). Chi-square test: $\chi^{2}=104.86 ; \mathrm{df}=12$; $\mathrm{a}=0.05 ; \chi_{\text {crit }}^{2}=21.03$; hypothesis that the whole profile is quasi-random was rejected.

\begin{tabular}{|c|c|c|c|c|c|c|}
\hline AF2 & $S$ & $\mathbf{M}$ & CL & $\mathrm{CC}$ & $\mathrm{C}$ & LL \\
\hline S & $\cdot$. & $146 / 84(+0.00)$ & $230 / 198(+0.02)$ & $113 / 127(-0.24)$ & $530 / 592(-0.01)$ & $10 / 26(-0.00)$ \\
\hline $\mathbf{M}$ & $140 / 82(+0.00)$ & & $85 / 84(+0.92)$ & $47 / 54(-0.37)$ & $202 / 252(-0.00)$ & $1 / 11(-0.00)$ \\
\hline CL & $266 / 196(+0.00)$ & $73 / 85(-0.18)$ & $\cdot \cdot$ & $61 / 128(-0.00)$ & $617 / 600(+0.49)$ & $13 / 26(-0.01)$ \\
\hline $\mathrm{CC}$ & $137 / 123(+0.22)$ & $35 / 54(-0.01)$ & $45 / 126(-0.00)$ & & $454 / 378(+0.00)$ & $28 / 17(+0.01)$ \\
\hline C & $424 / 544(-0.00)$ & $212 / 237(-0.10)$ & $610 / 557(+0.02)$ & $427 / 355(+0.00)$ & $\cdot \cdot$ & $102 / 73(+0.00)$ \\
\hline LL & $10 / 26(-0.00)$ & $2 / 11(-0.01)$ & $15 / 26(-0.03)$ & $31 / 16(+0.00)$ & $102 / 79(+0.01)$ & \\
\hline
\end{tabular}

Data: 335 boreholes, total profile length: $24.07 \mathrm{~km}, \mathrm{~m}=6$ lithofacies. Chi-square test: $\chi^{2}=382.22 ; \mathrm{df}=19 ; \mathrm{a}=0.05 ; \chi_{\text {crit }}^{2}=30.14$; hypothesis that the whole profile is quasi-random was rejected. 


\begin{tabular}{lccccccc}
\hline LS1 & S & M & CL & CC & C & LL \\
\hline S &.$\cdot$ & $21 / 6(+0.00)$ & $26 / 10(+0.00)$ & $14 / 7(+0.01)$ & $41 / 71(-0.00)$ & $20 / 28(-0.12)$ \\
M & $18 / 6(+0.00)$ & $\cdot$ & $6 / 9(-0.35)$ & $10 / 6(+0.10)$ & $70 / 63(+0.40)$ & $5 / 25(-0.00)$ \\
CL & $27 / 10(+0.00)$ & $10 / 9(+0.65)$ & $\cdot$ & $2 / 10(-0.01)$ & $105 / 104(+0.95)$ & $30 / 42(-0.07)$ \\
CC & $19 / 6(+0.00)$ & $3 / 6(-0.26)$ & $2 / 10(-0.01)$ & $\cdot$ & $59 / 68(-0.26)$ & $34 / 27(+0.20)$ \\
C & $41 / 68(-0.00)$ & $67 / 62(+0.55)$ & $110 / 104(+0.58)$ & $55 / 71(-0.05)$ &.$\cdot$ & $332 / 299(+0.06)$ \\
LL & $\mathbf{1 2 / 2 8 ( - 0 . 0 0 )}$ & $\mathbf{7 / 2 5 ( - 0 . 0 0 )}$ & $\mathbf{3 1 / 4 2 ( - 0 . 0 8 )}$ & $42 / 29(+0.02)$ & $337 / 305(+0.06)$ &.$\cdot$ \\
\hline
\end{tabular}

Data: 79 boreholes, total profile length: $6.55 \mathrm{~km}, \mathrm{~m}=6$ lithofacies. Chi-square test: $\chi^{2}=266.68 ; \mathrm{df}=19 ; \mathrm{a}=0.05 ; \chi_{\text {crit }}^{2}=30.14$; hypothesis that the whole profile is quasi-random was rejected.

\begin{tabular}{|c|c|c|c|c|c|c|}
\hline LS2 & $\mathrm{S}$ & $\mathbf{M}$ & CL & $\mathrm{CC}$ & C & LL \\
\hline S &.$\cdot$ & $X X X$ & XXX & XXX & $7 / 14(-0.07)$ & XXX \\
\hline $\mathbf{M}$ & $X X X$ & $\cdot$. & $X X X$ & $X X X$ & $X X X$ & XXX \\
\hline CL & XXX & $X X X$ & $\cdot \cdot$ & XXX & $32 / 29(+0.62)$ & $5 / 7(-0.37)$ \\
\hline $\mathrm{CC}$ & $X X X$ & $X X X$ & XXX &.$\cdot$ & $21 / 18(+0.49)$ & $X X X$ \\
\hline $\mathrm{C}$ & $9 / 16(-0.09)$ & $X X X$ & $27 / 27(+0.99)$ & $11 / 16(-0.23)$ &.. & $151 / 141(+0.41)$ \\
\hline LL & XXX & $X X X$ & $5 / 7(-0.46)$ & XXX & $143 / 144(-0.94)$ & $\cdot \cdot$ \\
\hline
\end{tabular}

Data: 34 boreholes, total profile length: $2.16 \mathrm{~km}, \mathrm{~m}=5$ lithofacies (without the $\mathrm{M}$ ). Chi-square test: $\chi^{2}=30.60 ; \mathrm{df}=12$; $\mathrm{a}=0.05 ; \chi_{\text {crit }}^{2}=21.03$; hypothesis that the whole profile is quasi-random was rejected.

\begin{tabular}{lcccc|cc}
\hline LE & S & M & CL & CC & C & LL \\
\hline S & $\cdot \cdot$ & $X X X$ & $42 / 6(+0.00)$ & $15 / 8(+0.01)$ & $37 / 88(-0.00)$ & $13 / 15(-0.57)$ \\
M & $X X X$ &.$\cdot$ & $27 / 8(+0.00)$ & $10 / 11(-0.81)$ & $104 / 119(-0.17)$ & $8 / 20(-0.01)$ \\
CL & $43 / 7(+0.00)$ & $\mathbf{2 6 / 8 ( + 0 . 0 0 )}$ & $\cdot$ & $19 / 32(-0.03)$ & $315 / 348(-0.08)$ & $51 / 60(-0.25)$ \\
CC & $\mathbf{1 5 / 8 ( + 0 . 0 2 )}$ & $9 / 10(-0.69)$ & $31 / 31(-1.00)$ &. & $485 / 439(+0.03)$ & $24 / 76(-0.00)$ \\
C & $42 / 92(-0.00)$ & $105 / 115(-0.36)$ & $296 / 345(-0.01)$ & $479 / 444(+0.10)$ &.$\cdot$ & $919 / 843(+0.01)$ \\
LL & $13 / 16(-0.41)$ & $5 / 21(-0.00)$ & $57 / 62(-0.54)$ & $49 / 79(-0.00)$ & $930 / 875(+0.06)$ &.$\cdot$ \\
\hline
\end{tabular}

Data: 354 boreholes, total profile length: $23.73 \mathrm{~km}, \mathrm{~m}=6$ lithofacies. Chi-square test: $\chi^{2}=736.72 ; \mathrm{df}=19 ; \mathrm{a}=0.05 ; \chi_{\text {crit }}^{2}=30.14$; hypothesis that the whole profile is quasi-random was rejected.

\begin{tabular}{|c|c|c|c|c|c|c|}
\hline LN & $S$ & $\mathbf{M}$ & CL & $\mathrm{CC}$ & $\mathrm{C}$ & LL \\
\hline$S$ &.$\cdot$ & $X X X$ & $X X X$ & $X X X$ & $33 / 49(-0.02)$ & $2 / 7(-0.07)$ \\
\hline $\mathbf{M}$ & $X X X$ & .. & $X X X$ & $X X X$ & $79 / 76(+0.75)$ & $2 / 11(-0.01)$ \\
\hline CL & $X X X$ & $11 / 5(+0.02)$ & $\cdot \cdot$ & $34 / 8(+0.00)$ & $100 / 129(-0.01)$ & $2 / 18(-0.00)$ \\
\hline $\mathrm{CC}$ & XXX & $2 / 6(-0.10)$ & $29 / 8(+0.00)$ & $\cdot \cdot$ & $145 / 144(+0.94)$ & $1 / 20(-0.00)$ \\
\hline $\mathrm{C}$ & $28 / 44(-0.01)$ & $82 / 78(+0.69)$ & $83 / 107(-0.02)$ & $109 / 119(-0.35)$ & $\cdot$ & $303 / 255(+0.00)$ \\
\hline LL & $3 / 6(-0.21)$ & $4 / 11(-0.04)$ & $0 / 15(-0.00)$ & $0 / 16(-0.00)$ & $294 / 253(+0.01)$ &.$\cdot$ \\
\hline
\end{tabular}

Data: 212 boreholes, total profile length: $11.30 \mathrm{~km}, \mathrm{~m}=6$ lithofacies. Chi-square test: $\chi^{2}=432.54 .72 ; \mathrm{df}=19 ; \mathrm{a}=0.05$; $X_{\text {crit }}^{2}=30.14$; hypothesis that the whole profile is quasi-random was rejected.

\begin{tabular}{|c|c|c|c|c|c|c|}
\hline G & S & M & CL & $\mathrm{CC}$ & $\mathrm{C}$ & LL \\
\hline$S$ & .. & $X X X$ & $4 / 6(-0.50)$ & $X X X$ & $23 / 29(-0.24)$ & $X X X$ \\
\hline $\mathbf{M}$ & $X X X$ &.$\cdot$ & $14 / 11(+0.45)$ & $7 / 8(-0.66)$ & $54 / 60(-0.42)$ & $X X X$ \\
\hline CL & $5 / 6(-0.76)$ & $13 / 12(+0.71)$ & .. & $5 / 17(-0.00)$ & $131 / 121(+0.35)$ & $X X X$ \\
\hline $\mathrm{CC}$ & $X X X$ & $11 / 9(+0.44)$ & $8 / 17(-0.03)$ &.. & $91 / 90(+0.89)$ & $X X X$ \\
\hline C & $1929 /(-0.06)$ & $52 / 60(-0.33)$ & $125 / 116(+0.43)$ & $93 / 117(+0.32)$ & $\cdot \cdot$ & $X X X$ \\
\hline LL & $X X X$ & $X X X$ & XXX & XXX & $X X X$ & .. \\
\hline
\end{tabular}

Data: 98 boreholes, total profile length: $9.36 \mathrm{~km}, \mathrm{~m}=5$ lithofacies (without the LL). Chi-square test: $\chi^{2}=50.79$; $\mathrm{df}=12$; $a=0.05 ; \chi_{\text {crit }}^{2}=21.03$; hypothesis that the whole profile is quasi-random was rejected. 


\begin{tabular}{|c|c|c|c|c|c|c|}
\hline PHW & $\mathrm{S}$ & $\mathbf{M}$ & CL & $\mathrm{CC}$ & C & LL \\
\hline $\mathrm{S}$ &.$\cdot$ & $18 / 10(+0.02)$ & $4 / 8(-0.14)$ & $5 / 6(-0.58)$ & $43 / 46(-0.61)$ & $X X X$ \\
\hline $\mathbf{M}$ & $19 / 11(+0.01)$ & . & $7 / 15(-0.04)$ & $5 / 12(-0.05)$ & $90 / 83(+0.47)$ & $X X X$ \\
\hline CL & $12 / 9(+0.25)$ & $18 / 15(+0.49)$ & $\cdot \cdot$ & $14 / 9(+0.13)$ & $58 / 68(-0.23)$ & $X X X$ \\
\hline $\mathrm{CC}$ & $7 / 7(-0.95)$ & $13 / 13(+0.94)$ & $5 / 10(-0.12)$ & $\cdot \cdot$ & $61 / 57(+0.55)$ & $X X X$ \\
\hline $\mathrm{C}$ & $33 / 44(-0.09)$ & $69 / 79(-0.28)$ & $79 / 62(+0.03)$ & $52 / 48(+0.58)$ &.$\cdot$ & $X X X$ \\
\hline LL & XXX & XXX & XXX & $X X X$ & $X X X$ &.. \\
\hline
\end{tabular}

Data: 95 boreholes, total profile length: $7.09 \mathrm{~km}, \mathrm{~m}=5$ lithofacies (without the LL). Chi-square test: $\chi^{2}=40.77 ; \mathrm{df}=12$; $a=0.05 ; \chi_{\text {crit }}^{2}=21.03$; hypothesis that the whole profile is quasi-random was rejected.

\begin{tabular}{lcccccc}
\hline PHE & S & M & CL & CC & C & LL \\
\hline S & $\cdot \cdot$ & $X X X$ & $X X X$ & $6 / 8(-0.46)$ & $67 / 70(-0.74)$ & XXX \\
M & $X X X$ &.$\cdot$ & $X X X$ & $X X X$ & $15 / 18(-0.48)$ & XXX \\
CL & $X X X$ & $X X X$ & $\cdot$ & $3 / 10(-0.03)$ & $86 / 84(+0.81)$ & $X X X$ \\
CC & $7 / 9(-0.47)$ & $X X X$ & $4 / 9(-0.09)$ & $\cdot$ & $333 / 328(+0.79)$ & $X X X$ \\
C & $75 / 79(-0.66)$ & $12 / 17(-0.22)$ & $85 / 79(+0.51)$ & $334 / 328(+0.72)$ &.$\cdot$ & $X X X$ \\
LL & $X X X$ & $X X X$ & $X X X$ & $X X X$ & $X X X$ &.$\cdot$ \\
\hline
\end{tabular}

Data: 225 boreholes, total profile length: $15.97 \mathrm{~km}, \mathrm{~m}=5$ lithofacies (without the LL). Chi-square test: $\chi^{2}=81.39$; $\mathrm{df}=12$; $a=0.05 ; \chi_{\text {crit }}^{2}=21.03 ;$ hypothesis that the whole profile is quasi-random was rejected. 